\title{
The Metabolic Profile in Laying Hens of the Rosso Race After 180 Days of Feed Supplement With Organic Selenium
}

\author{
Adrian RĂDUȚĂ*, Dumitru CURCĂ \\ Faculty ofVeterinary Medicine Bucharest, Splaiul Independenței no. 105, Bucharest, Romania. \\ *corresponding author: adrianraduta4u@yahoo.com
}

Bulletin UASVM Veterinary Medicine 73(2) / 2016,

Print ISSN 1843-5270; Electronic ISSN 1843-5378

DOI:10.15835/buasvmcn-vm: 12163

\begin{abstract}
Selenium is a trace mineral with antioxidant proprieties, which, by mediating the glutathione, indirectly protects the hemoglobin against the risk of oxidation by peroxides through three antioxidant enzymes: superoxide dismutase (SOD), glutathione peroxidase (GSH-Px) and catalase

The experiment was done on 20 laying chicks from the Rosso race, 6 weeks old at the start. The chicks were divided in 2 batche s, and one of the batches received feed enriched with organic selenium (Sel-Plex). After 180 days, biological samples were colected by cubital vein puncture and hematological and biochemical determinations were made. The results were tabled, graphically represented and biostatistically interpreted. In the experimental batch significant growths were observed in the erythrocyte constants: erithremie, hemoglobinemy, hematocrite and MCH. Of the biochemical markers significant growths were observed in the caso of ascorbic acid, alkalin phospahasie and selenium. The following parameters decrease significantly : proteinemia, amylase and MCV. Changes were also observed in the case of cholesterol, calcium, magnesium and other parameters, but without statisticaly value.

In the present paper we have shown the beneficial role of organic selenium on some haematological and biochemical markers, resulting in a growth of erythropoiesis, and at the same time a intensification of the metabolic processes in the experimental group.
\end{abstract}

Keywords: biochemestry, haemathology, laying hens, selenium.

\section{INTRODUCTION}

The role of selenium as a antioxidant is well documented, helping to protect haemoglobin againt peroxidation. This is possible with the help of three enzymes : glutathione peroxidase (GSHPX), superoxide dismutase (SOD) and catalase. (Curcă, 2008; Răduță, 2015). A deficiency of this element can lead to the peroxidation of cellular membranes and so to the release of prostaglandins (Răduță, 2011).

The peroxidation of cellular membranes will lead to the decline of several molecules, including
DNA molecules, and this phenomenon will lead to the progressive apeareance of neoplastic diseases (Ghergariu, 1980, Cantor, 2003, Curcă, 2005).

Disorders such as anemia and / or erythrocyte lysis were reported to be directly related to a deficiency in selenium, especially in rats, dogs, primates and also chickens. Supplementation with selenium of the feed regime could lead to the prevention of conditions such as myopathy effusion, bleeding diathesis etc.

The bioavailability of selenium is much better when administered in its organic form 
(selenomethionine), the total amount of selenium retained increases because these amino acids are not excreted in urine (Surai, 2006).

\section{MATERIALS AND METHODS}

The experiment was conducted in the biobase of the Veterinary Medicine Faculty of Bucharest, on two batches of laying hens, each batch consisting of 10 subjects 16 weeks old, in the period before egg laying. Both batches received the same feed regime, combined feed $21 / 5$, the feed recipe being : protein minerals and vitamins complex $10 \%$, corn $48 \%$, grain $27 \%$, soy $8 \%$, fish wheat $1 \%$, sunflower meal 6\% (figure 1). The feed recipe has the following nutritional values : metabolizable energy $2870,15 \mathrm{Kcal} / \mathrm{Kg}$, raw protein $15,60 \%$, methionine $0,29 \%$, lysine $0,70 \%$, fat $2,68 \%$, calcium $1,07 \%$, phosphorus $0,70 \%$.

One of the batches received the feed ration supplemented with organic selenium 1,38 ppm as Sel-Plex, made by AllTech, selenium yeast. After 180 days from the start of the experiment, biological samples were harvested, by cubital vein puncture, with EDTA anticoagulant, 1 - 2 $\mathrm{mg} / \mathrm{ml}$ blood, and respectively heparin, in order to perform biochemical and hematological determinations.

The count was made with a Coulter Counter automated machine, ACT 5 diff CP-Beckman analyser and respective with the wet Eppendorff
ECOM 1022 analyzer at the Diagnostic and Animal Health Institute in Bucharest.

Selenium calcium magnesium pyruvic acid and ascorbic acid levels were analyzed at the same institute using a spectrometer uv vis, wet biochemistry. Proteins, glucose, phospholipids, lipids, amylase, lipase alkaline phosphatase, and GOT levels were analyzed using theIdexx VetTest Chemestry Analyzer with the kits from Nova Group.

The statistical count of the determinations results were realised using the ANOVA program, and the data were processed using several programs from the Microsoft Office 2010 suite. The results were tabulated, plotted and interpreted biostatistically.

\section{RESULTS AND DISCUSSION}

In the batch whose feed was supplemented with organic selenium were found statistically significant increases in erythrocyte constants: erytremie, hemoglobin, hematocrit and $\mathrm{MCH}$ (fig. 1) . The following biochemical parameters increased statistically: acid ascorbic, alkaline phosphatase and serum selenium. (Table 1).

A statistically significant decrease was seen in the following parameters : MCV, proteins and amylasemia (fig. 2 and fig. 3 ).

Modifications of other parameters were seen, comparative between the two batches but without any statistical relevance. Upward trend compared

Tab. 1. The statiscicaly modified parameters (the control group and the experimental group)

\begin{tabular}{cccccc}
\hline Parameters & T Test & Mean dif. & Critical dif. & P value & Dif. \\
\hline E & M.vs.S & -.625 & .143 & $<.0001$ & $\uparrow \mathbf{S}$ \\
\hline Hb & M.vs.S & -.1 .077 & .493 & $\mathbf{. 0 0 0 2}$ & $\uparrow \mathbf{S}$ \\
\hline Ht & M.vs.S & -2.450 & 1.072 & $\mathbf{. 0 0 0 1}$ & $\uparrow \mathbf{S}$ \\
\hline MCV & M.vs.S & 11.900 & 5.794 & $\mathbf{. 0 0 0 4}$ & $\uparrow \mathbf{S}$ \\
\hline MCH & M.vs.S & 3.310 & 1.977 & $\mathbf{. 0 0 2 5}$ & $\uparrow \mathbf{S}$ \\
\hline Ascorbic acid & M.vs.S & -.468 & .422 & $\mathbf{. 0 3 1 7}$ & $\uparrow \mathbf{S}$ \\
\hline Proteins & M.vs. S & .538 & .448 & $\mathbf{. 0 2 1 3}$ & $\downarrow \mathbf{S}$ \\
\hline Amylase & M.vs. S & 100.467 & 78.085 & $\mathbf{0 . 1 4 6}$ & $\downarrow \mathbf{S}$ \\
\hline Alkaline phosphatase & M.vs.S & -2.394 & 2.162 & $\mathbf{. 0 3 1 9}$ & $\uparrow \mathbf{S}$ \\
\hline Selenium & M.vs.S & -13.947 & 1.901 & $<.0001$ & $\uparrow \mathbf{S}$ \\
\hline $\begin{array}{c}\text { E- erytremia (RBC); Hb - hemoglobin; Ht - Hematocrit; MCV - mean corpuscular volume } \\
\text { MCH - mean corpuscular haemoglobin; M. vs. S - martor vs. selenium }\end{array}$
\end{tabular}




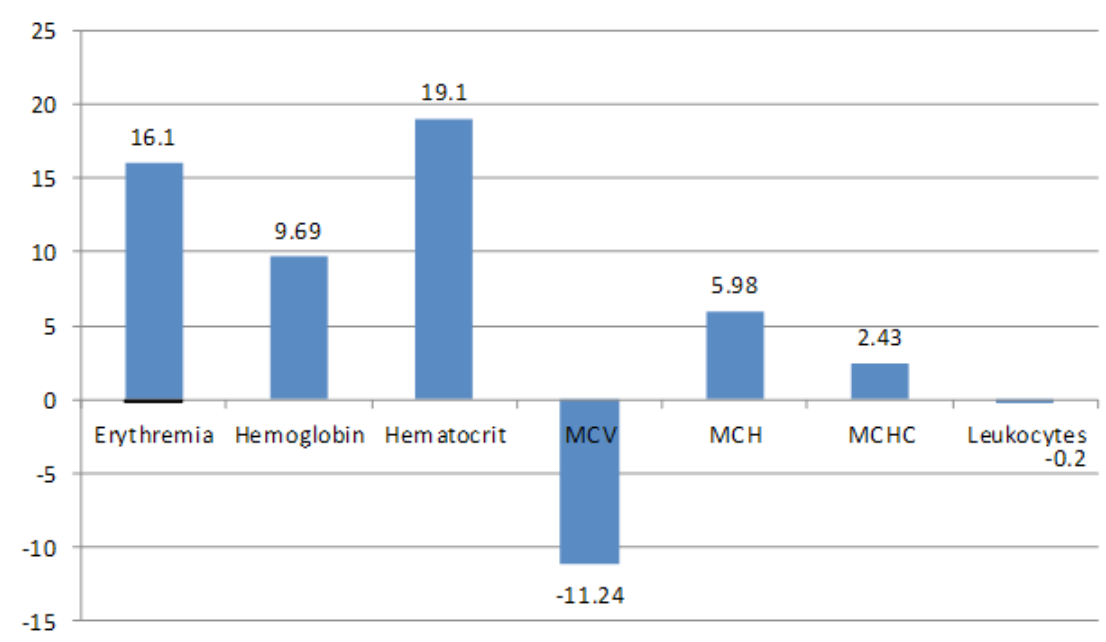

Fig. 1. The percentage changes of hematological parameters in chickens whose diet was supplemented with selenium compared with the values of the control batch

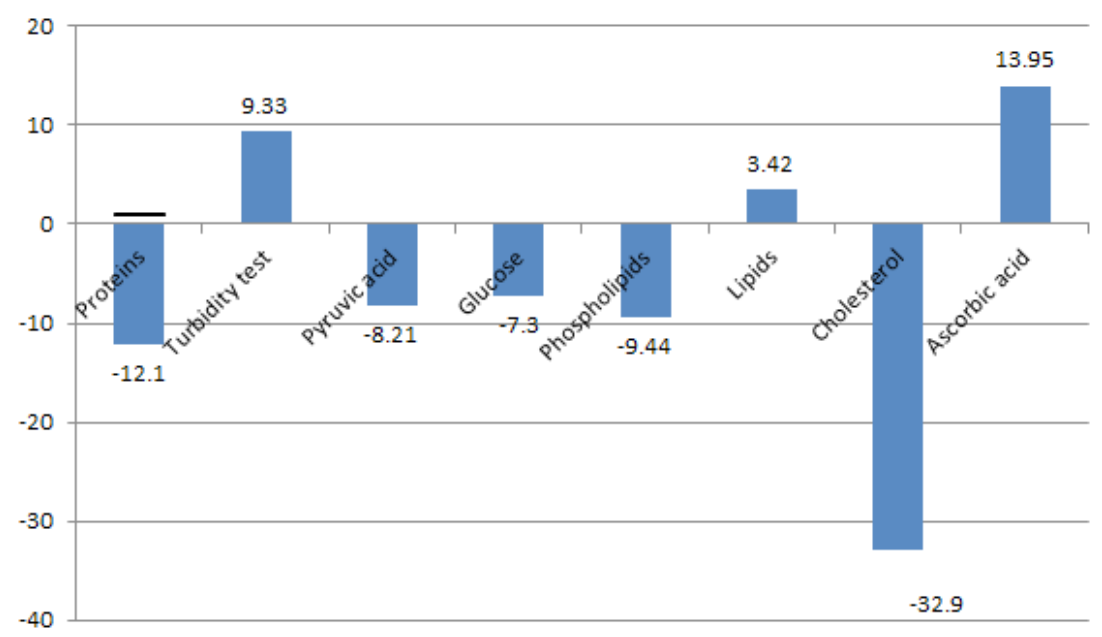

Fig. 2. Percentage changes of biochemical indices in chickens whose diet was supplemented with organic selenium

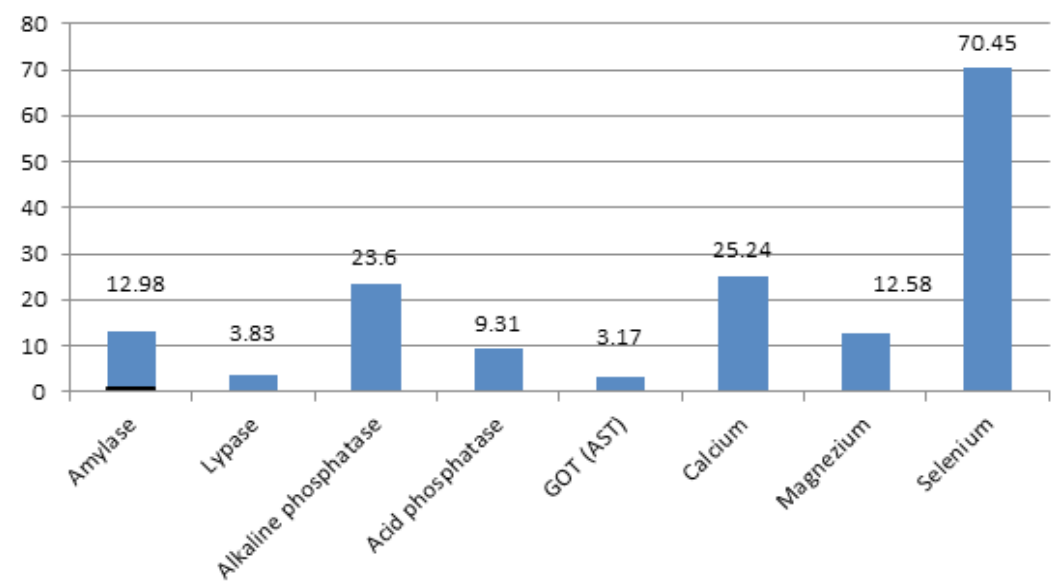

Fig. 3. The percentage changes in indices reared enzyme in chickens whose diet was supplemented with organic selenium 
to the control group showed: MCHC, lipids, calcium, magnesium, GOT, acid phosphatase and pseudocholinesterase .

Downward trend compared to the values registered in the control group showed: leukocytes, blood glucose, phospholipids, cholesterol and pyruvic acid levels.

Organic selenium intake in the diet led to an increased erythropoiesis so erythremia shows an increase compared to the group not receiving the selenium supplement by $16.1 \%$. (Curcă and Răduță, 2015)

Also hemoglobin level increases by $9.69 \%$, due to increased number of young red blood cells from the bloodstream. Thus mean erythrocyte hemoglobin $(\mathrm{MCH})$ is higher by $0.15 \%$ compared to the value recorded in the control group, the higher erythrocyte count in the hemoglobin is relevant and statistically. (Smith and Picciano, 1987).

Consecutive with the intensification of eritrogenesys, the blood-forming marrow issues a greater number of young red blood cells, the hematocrit value increases in the experimental group by $19.1 \%$. This statistically significant increase in hematocrit suggests an increase in cell mass at the expense of plasma mass. (Surai, 2002)

Decreased mean corpuscular volume (MCV) is due to the large number of young red blood cells recently put into circulation. These present a lower volume than normal volume of a mature red blood cell, MCV has a $11,24 \%$ decrease than the control group. (Popescu and Popescu, 1990).

The value increased by $2.43 \%$ of the mean corpuscular hemoglobin concentration (MCHC) can be explained by correlating this value, statistically significant with elevated hemoglobin, hematocrit and erythremia levels. Leukocytes count shows a downward trend, but insignificant in statistical terms.

As to the biochemical aspect ascorbic acid levels, presented an outstanding growth trend in the batch of chicks whose diet was supplemented with organic selenium, mean of the ascorbic acid levels in the experimental group was $2.99 \mathrm{mg} / \mathrm{dl}$ blood, with a growth of $13.95 \%$.

The pyruvic acid level, had a decreasing trend, the decrease was $8.21 \%$. Lipids in the experimental group, reached the value of 513.9 $\mathrm{mg} / \mathrm{dl}$ blood serum, thus registering an increase of $3.42 \%$ compared to the control group.
The downward trend of the lipase, denotes a better absorption of lipids and a thereof increased hydrolysis in the digestive tract, resulting in a higher absorption of vitamin E, thus avoiding pancreas necrosis dystrophy (Aye et al., 1999, Agate et al., 2000, Apsite, et al, 1993, Mahan, 1995, Poll, 1968).

Increased activity of the acid phosphatase and alkaline phosphatase show an increase in the permeability of cell membranes and in particular in the sarcolemma, so that the enzymes leave the cytosol passing into the bloodstream, this can lead to the establishment of muscle degeneration without evidence of this in the necropsy. (Oster and Prellwitz 1990, Bansal and Kaur, 2002, Pappas, et al., 2004) .

The mean values of the amylase in the batch of chickens in the experimental group was 723.575 UA-Smith-Roe, meaning a significant downward trend, with $12.98 \%$ from the average values recorded in the control group.

Cholesterolaemia shows a downward trend in the group that received supplementation of the feed regime with selenium, but statistically insignificant, the average value determinations of $78.2 \mathrm{mg} / \mathrm{dl}$ in the experimental group opposed to $109.1 \mathrm{mg} / \mathrm{dl}$ in the control group (Cornell University College of Veterinary Medicine, 2011)

This values can be interpreted as improving the production of lipid metabolites without intermediaries. In the experimental group was observed a marked decrease in blood glucose this being $223.1 \mathrm{mg} / \mathrm{dl}$ blood, $7.30 \%$ lower than the control group.

Both calcium and magnesium have a tendency of incresing in the experimental group. Mean serum calcium in the experimental group was $15.08 \mathrm{mg} / \mathrm{dL}$ blood and the mean in the control group was $1.7 \mathrm{mg} / \mathrm{dl}$ blood. Magnesium also tended to increase, its value being $12.58 \%$ higher in the experimental group.

The trend of increase in calcium and magnesium in the control group, indicates a higher mineral metabolism unlike the control group. This is especially beneficial to specialized birds for egg production, they lose a significant amount of minerals in eggshell formation. Thus improving mineral metabolism, different osteoarticular affections are avoided in birds reared in batteries (Allan et al. 2000, Apsite, 1994). 
The mean peak serum selenium in the group of chickens that received feed supplemented with organic selenium was $21.63 \%$, opposed to $10.36 \%$ the average recorded in the control group $(21.63 \%$ is the distinct difference statistically significant).

Selenium presents a very defined role in its synergy with vitamin E, thus ensuring the body defenses against oxidative stress (Surai, 2000). Also selenium, according to the literature has a particularly important role in preventing many types of nutritional disorders, including: diathesis exudative, muscular atrophy, pancreatic atrophy, necrosis of the liver, reproductive disorders, immune deficiency disorders, osteo-articular disorders etc. (Wepruk, 2003).

\section{CONCLUSION}

In the conditions of the current experiment we can see the beneficial effect of feed suplimenting with Sel-Plex, by improving certain biochemical and haematological markers, which are factors in preventing states of myopathy exudative, hemorrhagic diathesis and encephalomalacia also ensuring better body development, an index of feed conversion best reared in the experimental group.

Also, one of the biological roles of selenium could be observed, that of its implication in the acceleration of the hematopoietic bone marrow activity, and so its role in the formation of new red blood cells.

By stimulating the erythropoiesis, increasing the red blood cell count, and the haemoglobin, selenium may help to a better tissue oxygenation, so to an increase of the basal metabolism, therefore promoting the growing processes, but also optimizing the productive parameters.

The increase or decrease of these biochemical parameters subsequently to the supplementation of the fodder with organic selenium will result in the prevention of oxidative stress and into a higher efficiency of fodder conversion rate.

\section{REFERENCES}

1. Allan CB, Lacourciere GM, Stadtman TC (2000). Responsiveness of selenoproteins to dietary selenium. Ann Rev Nutr 19:1-16.

2. Agate DD, O’Dea EE, Rustad, ME (2000). Effects of dietary selenium on laying henfertility as assessed by the periviteline sperm hole assay. Proceedings of the Poultry Research and Production Symposium, Alberta Poultry Research Centre, p. 1-4
3. Apsite M, Pitrans, B, Atlavin A (1994). Absorption of ${ }^{75} \mathrm{Se}$-selenate and ${ }^{75} \mathrm{Se}$-selenite in chicks. In: Mengen-und Spurenelemente, Edited by Anke, M and Meissner, D, Arbeitstagung, Jena, p. 188.

4. Apsite M, Pitrans B V, Atlavin AB (1993). The rol of duodenum in selenium assimilation in chick organism. Trace elements in man and animals. Proceedings of the Eight International Symposium on Trace Elements in Man and Animals, TEMA 8: p. 392-393

5. Aye P P, Morishita T Y, Grimes S, Skowronek A and Mohan $R$ (1999). Encephalomalacia associated with vitamin E deficiency in commercially raised emus. Avian Diseases 42: 600-605.

6. Combs Jr. GF, Combs SB (1986). The role of selenium in nutrition. Academic Press, Boca Raton, Florida.

7. Bansal MP and Kaur T (2002). Growth characteristics and selenium status changes of yeast cells with inorganic and organic selenium supplementation: selenium a chemopreventive agent. J Medicinal Food 5: 85-90

8. Curcă D (2005). Faza 2. Acţiunea Sel-Plex-ului în prevenirea miopatiei exsudative, diatezei hemoragice şi encefalomalaciei la păsările ouătoare şi la puii de carne. GRANT - 33378/29.06.2004, act adiţional $34659 / 24.06 .2005$

9. Curcă D (2008). Fiziopatologie - Lucrări practice şi protocoale experimentale/Ediţia a IIIa. Editura Printech. p. 180-195, ISBN 973-718-338-X.

10. Curcă D (2008). Tratat de Fiziopatologie generală - Ediţia a-IIIa. Editura Printech. p. 253-384, ISBN 973-718-418-1.

11. Ghergariu S (1980). Oligominerale și oligomineraloze. Ed. Academiei Române, București, p. 19-59

12. Oster 0, Prellwitz W (1990). The renal excretion of selenium. Biological Trace Element Research 24: 119-146

13. Jackie Wepruk (2003) "Cum să atingem un echilibru între producție și bunăstare?" Raport produs pentru Alberta Farm Animal Care Association.

14. Pappas AC, McDevitt R M, Surai PF, Acamovic T, and Sparks NHC (2004). Influence of the dietary fatty acids profile on the assimilation of seleniumin tissues and eggs of breeders and in thetissues of the day old broiler chick. Nutritional Biotechnology in the Feed and Food Industry. Proceedings of the 20th Annual Symposium, May 22-26, 2004, Lexington, Kentucky, USA, p.17.

15. Poll E (1968). Contribuţii la rolul seleniului în patologia puilor de găină. PhD Diss., FMV Bucureşti.

16. Popescu Aristide L, Popescu Aristide N (1990). Stresul la animalele de fermă. Ed. Ceres, București

17. Răduță A, Curcă D, Lionide A (2015). Profilul metabolic la puicuțele a căror hrană a fost suplimentată cu seleniu organic și respectiv l-carnitină. Congresul Național de Fiziopatologie cu participare internațională Clasic și Modern în Fiziopatologie, Ed. Gr. T. Popa, Iași. 236-241.

18. Răduță A (2011). Efectele suplimentării hranei cu seleniu și respectiv l-carnitină la puicuțe. Lucrare de licență, Universitatea de Științe Agronomice și Medicină 
Veterinară, Facultatea de Medicină Veterinară, București, România, p. 42.

19. Smith, AM and Picciano, MF (1987). Relative bioavailability of seleno-compounds in the lacting rat. The journal of Nutrition 117: 725-731

20. Surai PF (2000). Organic selenium: benefits to animals and humans, a biochemist's view. In: Biotechnology in the Feed Industry: Proceedings of Alltech's 16 th Annual
Symposium (T P Lyons and K A Jacques, eds), Nottingham University Press, Nottingham, UK, p. 205-260.

21. Surai PF (2002). Natural Antioxidants in Avian Nutrition and Reproduction. Nottingham University Press, Nottingham.

22. Surai PF (2006). Selenium in Nutrition and Health. Nottingham University Press. 